DOI: $10.19195 / 0137-1134.113 .12$

\author{
MACIEJ JAKUB ZIELIŃSKI
}

Uniwersytet im. Adama Mickiewicza w Poznaniu

\title{
KONTROWERSJE WOKÓ£ WYKONYWANIA PRACY NA RZECZ WŁASNEGO PRACODAWCY W ROZUMIENIU ART. 8 UST. 2A USTAWY O SYSTEMIE UBEZPIECZEŃ SPOŁECZNYCH A ZGODNOŚĆ TEGO PRZEPISU Z KONSTYTUCJĄ RP*
}

\begin{abstract}
Abstrakt: Artykuł poświęcony jest kontrowersjom wokół wykładni wyrażenia „wykonywanie pracy na rzecz własnego pracodawcy" w rozumieniu art. 8 ust. 2a ustawy o systemie ubezpieczeń społecznych w kontekście zgodności tego przepisu z Konstytucją RP. Autor poddaje krytyce sposób wykładni tego zwrotu, oparty wyłącznie na abstrakcyjnie sformułowanych tezach poszczególnych rozstrzygnięć sądowych, w tym zwłaszcza Sądu Najwyższego, które oderwane od konkretnych stanów faktycznych mogą prowadzić do rozszerzającej i nieuzasadnionej interpretacji tego przepisu. Wyrażenie „wykonywanie pracy na rzecz własnego pracodawcy” należy rozumieć przez pryzmat relacji zachodzącej w typowym stosunku pracy. W konfiguracji trójpodmiotowej, gdy mamy do czynienia ze świadczeniem usługi na rzecz pracodawcy, a rolą podmiotu trzeciego jest w istocie pośrednictwo pracy (co zbliżałoby przedmiot jego działalności do agencji pracy tymczasowej), skutkuje to uznaniem, że w ramach umowy-zlecenia świadczona jest praca na rzecz pracodawcy. Zupełnie inaczej przedstawia się natomiast sytuacja, gdy podmiot trzeci zobowiązany jest do dostarczania pracodawcy określonego produktu, który wytwarza w ramach prowadzonej przez siebie działalności. Wówczas kluczowe jest ustalenie, czy ponosi on ryzyko organizacyjne, techniczne, produkcyjne, a także osobowe za produkt przez siebie wytwarzany. Rozważania prowadzą ponadto do wniosku, że utrwalone w orzecznictwie rozumienie omawianego przepisu pozostaje w sprzeczności z zasadą zaufania obywateli do państwa i stanowionego przez nie prawa. $Z$ kolei sam art. 8 ust. 2a ustawy o systemie ubezpieczeń społecznych, przynajmniej w zakresie, w jakim odnosi się do sytuacji, gdy osoba zatrudniona przez podmiot trzeci na podstawie umowy cywilnoprawnej wykonuje w ramach tej umowy pracę na rzecz swojego pracodawcy, wywołuje istotne zastrzeżenia w zakresie jego zgodności z art. 217 oraz art. 64 ust. 3 Konstytucji RP. W opracowaniu sformułowano w związku z tym wnioski de lege ferenda.
\end{abstract}

Słowa kluczowe: pracodawca, ubezpieczenie społeczne, wykonywanie pracy na rzecz własnego pracodawcy

* Opracowanie stanowi uzupełnioną wersję referatu wygłoszonego podczas Ogólnopolskiej Konferencji Naukowej pt. „Pojęcie pracodawcy w prawie pracy i ubezpieczeń społecznych” we Wrocławiu w dniu 17 listopada $2017 \mathrm{r}$. 


\section{WPROWADZENIE}

Artykuł 8 ust. 2a ustawy z dnia 13 października 1998 r. o systemie ubezpieczeń społecznych (Dz.U. z 2017 r. poz. 177, ze zm., dalej: ustawa systemowa) stanowi, że za pracownika, w rozumieniu tej ustawy, uważa się także osobę wykonującą pracę na podstawie umowy agencyjnej, umowy-zlecenia lub innej umowy o świadczenie usług, do której zgodnie z kodeksem cywilnym stosuje się przepisy dotyczące zlecenia albo umowy o dzieło, jeżeli umowę taką zawarła z pracodawcą, z którym pozostaje w stosunku pracy, lub jeżeli w ramach takiej umowy wykonuje pracę na rzecz pracodawcy, z którym pozostaje w stosunku pracy.

Celem niniejszego opracowania jest omówienie głównych problemów w zakresie wykładni zawartego w przepisie wyrażenia ,wykonywanie pracy na rzecz pracodawcy" w kontekście oceny jego zgodności z przepisami Konstytucji RP ${ }^{1}$. Mimo że przepis ten był przedmiotem wielu wypowiedzi i w doktrynie ${ }^{2}$, i w orzecznictwie sądowym ${ }^{3}$, to nadal nie usunięto wątpliwości związanych z jego wykładnią. Odnosi się to zwłaszcza do jego części dotyczącej sytuacji, gdy wymieniona w nim strona umowy cywilnoprawnej wykonuje w ramach tej umowy pracę na rzecz pracodawcy, z którym pozostaje w stosunku pracy. Przed Trybunałem Konstytucyjnym, z wniosku Prezydenta Konfederacji Lewiatan oraz Pracodawców RP, toczy się obecnie sprawa o stwierdzenie jego niekonstytucyjności (sygn. K 15/16 ${ }^{4}$ ). $\mathrm{W}$ związku z tym tytułowa problematyka wydaje się niezwykle aktualna.

\section{GENEZA I CELE REGULACJI ART. 8 UST. 2A USTAWY O SYSTEMIE UBEZPIECZEŃ SPOŁECZNYCH}

Artykuł 8 ust. 2a został wprowadzony do ustawy systemowej na mocy ustawy z dnia 23 grudnia 1999 r. o zmianie ustawy o systemie ubezpieczeń społecznych oraz niektórych innych ustaw ${ }^{5}$. W projekcie tego ostatniego aktu prawnego nie przedstawiono szerszego uzasadnienia konstrukcji uznania za pracownika, o której mowa w art. 8 ust. 2a ustawy systemowej. Trudno jednak nie zgodzić się

1 Konstytucja Rzeczypospolitej Polskiej z dnia 2 kwietnia 1997 r. (Dz.U. z 1997 r. Nr 78, poz. 483$)$.

2 Zob. np. I. Jędrasik-Jankowska, Konstrukcja uznania za pracownika w prawie ubezpieczenia społecznego, „Praca i Zabezpieczenie Społeczne” 2011, nr 8; S. Koczur, Beneficjent pracy jako kryterium objęcia systemem ubezpieczeń społecznych, „Monitor Prawa Pracy” 2013, nr 7; P. Prusinowski, Obowiazek zapłaty składek a definicja pracownika w prawie ubezpieczeń społecznych, „Monitor Prawa Pracy” 2011, nr 6.

3 Zob. uchwała Sądu Najwyższego z dnia 2 września 2009 r., II UZP 6/09, OSNP 2010, nr 3-4, poz. 46; oraz wyroki: z dnia 22 lutego 2010 r., I UK 259/09, LEX nr 585727; z dnia 18 października 2011 r., III UK 22/11, OSNP 2012, nr 21-22, poz. 266.

${ }^{4}$ Zob. http://ipo.trybunal.gov.pl/ipo/Sprawa?\&pokaz=dokumenty\&sygnatura=K\%2015/16 (dostęp: 15.01.2018).

5 Dz.U. z 1999 r. Nr 110, poz. 1256. 
z J. Jończykiem, że celem tego przepisu było przeciwdziałanie unikaniu obowiązków składkowych wskutek zawierania umów pozornych ${ }^{6}$. W orzecznictwie z zakresu prawa pracy stosunkowo wcześnie dostrzeżono bowiem praktykę zatrudniania pracowników ponad wynikające z kodeksu pracy normy czasu pracy w ramach umów cywilnoprawnych przy pracach tego samego rodzaju, co objęte jest stosunkiem pracy, i przyjęto, że jest to obejście przepisów ${ }^{7}$. O ile jednak takie zapatrywanie dało się łatwo stosować w sporach z zakresu prawa pracy, o tyle było o wiele bardziej skomplikowane w sporach z zakresu ubezpieczeń społecznych. Artykuł 8 ust. 2 ustawy systemowej eliminował w takich przypadkach konieczność żmudnego ustalania, że umowa cywilnoprawna była zawarta dla pozoru, a obowiązki z niej wynikające były w istocie kontynuowaniem stosunku pracy. W tym sensie miał on stanowić ułatwienie dla Zakładu Ubezpieczeń Społecznych w zakresie przeciwdziałania nadużyciom wynikającym ze stosowania zatrudnienia niepracowniczego. Celem omawianej regulacji było także zapobieganie obchodzeniu przepisów dotyczących obowiązku składkowego z wykorzystaniem unormowań dotyczących zbiegu tytułów ubezpieczenia oraz z wykorzystywaniem umów, które w ogóle nie podlegają obowiązkowi ubezpieczenia społecznego (na przykład umowy o dzieło). Najlepszą ilustracją tego typu działań prawodawczych są zmiany w systemie ubezpieczeń społecznych, jakie weszły w życie z dniem 1 stycznia 2016 r. (chodzi o oskładkowanie przychodów także z innych niż pierwsze zlecenie tytułów ubezpieczenia emerytalnego i rentowego, jeśli w ramach tej umowy podstawa wymiaru składek na ubezpieczenia emerytalne i rentowe w danym miesiącu jest niższa od minimalnego wynagrodzenia za pracę - art. 9 ust. 2c ustawy systemowej). Wprowadzenie wyjątków od generalnych reguł dotyczących zbiegu tytułów ubezpieczenia służyło (i nadal służy) przeciwdziałaniu praktykom występującym na rynku pracy, polegającym na wypłacie wynagrodzenia bez obowiązku zapłaty od niego składki na ubezpieczenia społeczne. Takie działania mają znaczenie dla: 1. zmniejszania kosztów zatrudnienia (z perspektywy pracodawcy), 2. zwiększania wypłacanego wynagrodzenia (z perspektywy pracownika) oraz 3. zmniejszania wpływów składkowych (perspektywa ZUS i państwa).

\section{NORMATYWNA TREŚĆ ART. 8 UST. 2A USTAWY O SYSTEMIE UBEZPIECZEŃ SPOŁECZNYCH I OCENA JEGO ZGODNOŚCI Z KONSTYTUCJĄ RP}

Regulacja art. 8 ust. 2a ustawy systemowej rozszerza zakres pojęcia pracownika w stosunku do art. 8 ust. 1 tej ustawy, zgodnie z którym pracownikiem jest

6 J. Jończyk, Prawo zabezpieczenia społecznego, Kraków 2006, s. 94-95.

7 Zob. wyroki: Sądu Najwyższego z dnia 30 czerwca 2000 r. II UKN 523/99, OSNP 2002, nr 1, poz. 22; Sądu Apelacyjnego w Gdańsku z dnia 21 października 1994 r., III AUa 865/94, „Prawo Pracy" 1995, nr 2, s. 40; Sądu Najwyższego z dnia 12 kwietnia 1994 r., I PZP 13/94, LEX nr 11794. 
osoba pozostająca w stosunku pracy. Wobec braku w ustawie systemowej autonomicznej definicji tego terminu na gruncie art. 8 ust. 1 ustawy systemowej należy go bowiem rozumieć w ten sposób, że chodzi tu o osobę, o której mowa w art. 2 k.p., a zatem zatrudnioną na podstawie umowy o pracę, powołania, wyboru, mianowania lub spółdzielczej umowy o pracę $^{8}$. W tym znaczeniu art. 8 ust. 2a ustawy systemowej wprawdzie odnosi się do pracownika, niemniej wpływa bezpośrednio na zakres obowiązków innych podmiotów pozostających w stosunkach prawnych z osobą uznaną na jego podstawie za pracownika.

Hipoteza normy prawnej wyrażonej w omawianym przepisie wskazuje, że zasadniczo możemy mieć do czynienia z dwiema sytuacjami. W pierwszej ubezpieczonego i pracodawcę łączy zarówno stosunek cywilnoprawny, jak i stosunek pracy (verba legis: ,jeżeli umowę taką [tj. umowę-zlecenie, inną umowę o świadczenie usług, do której stosuje się przepisy dotyczące zlecenia, albo umowę o dzieło - przyp. M.J.Z.] zawarła z pracodawcą, z którym pozostaje w stosunku pracy"). W zasadzie jest to wyjątek od ogólnej reguły dotyczącej zbiegu tytułów do ubezpieczenia, wyrażonej w art. 9 ust. 1 ustawy systemowej. Jednoczesne pozostawanie w dwóch stosunkach prawnych przez te same podmioty (w stosunku pracy i stosunku cywilnoprawnym, na podstawie których wykonywana jest praca) powoduje, że pracownik (będący jednocześnie zleceniobiorcą, wykonawcą itp.) podlega obowiązkowi ubezpieczenia z dwóch tytułów (a nie z jednego, tak jak to wynikałoby z art. 9 ust. 1 ustawy systemowej). W omawianej sytuacji w art. 8 ust. 2 a ustawy systemowej chodzi nie tyle, jak wynikałoby to z literalnego brzmienia tego przepisu, o uznanie, że osoba zatrudniona przez własnego pracodawcę na podstawie umowy cywilnoprawnej jest pracownikiem, ile o traktowanie przychodu uzyskiwanego w ramach takiej umowy jak przychodu ze stosunku pracy. Nie decyduje o tym ani przedmiot, ani sposób wykonywania umowy, lecz jednoczesne pozostawanie jej stron w innym stosunku prawnym — stosunku pracy ${ }^{9}$. Początkowo zresztą art. 8 ust. 2a ustawy systemowej odnoszono jedynie do więzi prawnych między tym samym płatnikiem a ubezpieczonym ${ }^{10}$. W takim ujęciu niezbędna była tożsamość stron umowy o pracę i umowy cywilnoprawnej ${ }^{11}$.

8 Por. wyrok Sądu Najwyższego z dnia 18 października 2011 r., III UK 22/11, OSNP 2012, nr 21-22, poz. 266.

9 Ustawa o systemie ubezpieczeń społecznych. Komentarz, red. B. Gudowska, J. Strusińska-Żukowska, Warszawa 2014, komentarz do art. 8, Nb. 104.

10 Por. Z. Kubot, Szczególne formy zatrudnienia i samozatrudnienia, [w:] Szczególne formy zatrudnienia, red. Z. Kubot, Wrocław 2000, s. 26; K. Antonów, Zakres podmiotowy obowiazkowego ubezpieczenia emerytalnego, [w:] Konstrukcje prawa emerytalnego, red. T. Bińczycka-Majewska, Kraków 2004, s. 100-101.

11 Tak, choć bez wyraźnego odwołania do art. 8 ust. 2a ustawy systemowej, I. Jędrasik-Jankowska, Pojęcia i konstrukcje prawne ubezpieczenia społecznego, t. 1, Warszawa 2006, s. 76. 
Mimo że nie zawsze jest to akcentowane w doktrynie ${ }^{12}$, wyrażenie ,pracodawca, z którym pozostaje w stosunku pracy" odnosi się do pracodawcy w takim ujęciu, w jakim występuje on w art. 3 k.p. Tylko taki pracodawca może bowiem być stroną indywidualnego stosunku pracy. Takie zapatrywanie przyjmuje się zarówno piśmiennictwie ${ }^{13}$, jak i w orzecznictwie Sądu Najwyższego, w którym ugruntowany jest pogląd, że użyte w art. 8 ust. 2a ustawy systemowej określenie „pracodawca” należy pojmować w znaczeniu, jakie nadaje mu art. 3 k.p. ${ }^{14}$ Stąd też słusznie Sąd Najwyższy uznał w uchwale z dnia 16 czerwca 2016 r., III UZP 6/16, że jedynie spółka kapitałowa wchodząca w skład ,holdingowej struktury organizacyjnej spółek handlowych" może być pracodawcą, o którym mowa w art. 8 ust. 2a ustawy systemowej, a nie ta struktura (holding, grupa kapitałowa).

Druga sytuacja objęta zakresem zastosowania normy prawnej wyrażonej w art. 8 ust. 2a ustawy systemowej jest zdecydowanie bardziej złożona. Za pracownika uważa się bowiem także osobę wykonującą pracę na podstawie umowy agencyjnej, umowy-zlecenia lub innej umowy o świadczenie usług, do której zgodnie z kodeksem cywilnym stosuje się przepisy dotyczące zlecenia albo umowy o dzieło, jeżeli w ramach takiej umowy wykonuje pracę na rzecz pracodawcy, z którym pozostaje w stosunku pracy. Oznacza to, że obok stosunku pracy pojawia się stosunek cywilnoprawny zawarty z podmiotem trzecim, w ramach którego osoba zatrudniona (zleceniobiorca, przyjmujący zamówienie itp.) wykonuje jednak pracę na rzecz pracodawcy, z którym jednocześnie pozostaje w stosunku pracy ${ }^{15}$.

W tym zakresie treść normatywna art. 8 ust. 2a ustawy systemowej nie jest do końca jasna i czytelna. Z pewnością udział podmiotu trzeciego w okolicznościach opisanych w tym przepisie prowadzi do uznania osoby tam wskazanej za pracownika i objęcia jej obowiązkowymi i ubezpieczeniami: emerytalnym, rentowym, chorobowym, wypadkowym (art. 6 ust. 1 pkt 1, art. 11 ust. 1 i art. 12 ust. 1 ustawy systemowej). Pojawia się jednak pytanie, w jakich sytuacjach dopuszczalne jest przyjęcie, że praca świadczona na podstawie umowy cywilnoprawnej zawartej z podmiotem trzecim (niebędącym pracodawcą) jest wykonywana właśnie „na rzecz pracodawcy". W uzasadnieniu projektu wprowadzającego art. 8 ust. 2a do ustawy systemowej wskazywano, że regulacja ta rozszerzy obowiązek opłacania składek na ubezpieczenia społeczne na przychody z umów zlecenia i o dzieło zawartych z tym samym pracodawcą ${ }^{16}$. Oznacza to, że projektodawca wskazał

12 Por. J. Jończyk, op. cit., s. 43; G. Szpor, System ubezpieczeń społecznych. Zagadnienia podstawowe, Warszawa 2009, s. 57; D. Lach, [w:] Ustawa o systemie ubezpieczeń..., komentarz do art. $4, \mathrm{Nb} .4$.

13 Por. D. Dzienisiuk, Prawo pracy a prawo ubezpieczeń społecznych, Warszawa 2016, s. 146.

14 Por. wyrok Sądu Najwyższego z dnia 18 października 2011 r., III UK 22/11, OSNP 2012, nr 21-22, poz. 266; oraz wyrok Sądu Najwyższego z dnia 13 lutego 2014 r., I UK 323/13, OSNP 2015, nr 5, poz. 68 .

15 S. Koczur, op. cit., s. 351; zob. też uzasadnienie uchwały Sądu Najwyższego z dnia 2 września 2009 r., II UZP 6/09, LEX nr 11794.

16 Zob. druk sejmowy III kadencji nr 1480. 
jedynie na pierwszą z wymienionych sytuacji objętych hipotezą art. 8 ust. 2a ustawy systemowej. Nie odniósł się natomiast w ogóle do drugiego z opisanych przypadków. Nie powinno jednak budzić wątpliwości, że ratio legis przedmiotowej regulacji jest podobne jak w sytuacji pierwszej. Chodzi mianowicie o ograniczenie możliwości wykorzystywania regulacji dotyczących zbiegu tytułów ubezpieczenia przez powoływanie podmiotów gospodarczych służących wyłącznie wykorzystywaniu możliwości zmniejszania obciążeń składkowych.

\section{WYKONYWANIE PRACY NA RZECZ PRACODAWCY W ROZUMIENIU ART. 8 UST. 2A USTAWY O SYSTEMIE UBEZPIECZEŃ SPOŁECZNYCH}

Jak wskazano powyżej, ustalenie „na rzecz” kogo wykonywane jest zatrudnienie (bez względu na stosowaną konstrukcję stosunków prawnych zachodzących między określonymi podmiotami) uzasadnia uznanie tego zatrudnienia za podlegające składce na ubezpieczenie społeczne. Nie jest jednak tak, że zawsze gdy „pojawia się” podmiot trzeci w układzie zależności prawnych wskazanych w art. 8 ust. 2a ustawy systemowej, należy przyjmować, że zostały spełnione przesłanki zastosowania przedmiotowego unormowania. Podstawowe jest bowiem ustalenie normatywnej treści zwrotu „na rzecz pracodawcy”. W dużym stopniu będzie to zależało od okoliczności konkretnej sprawy. Stąd też istnieje wysokie ryzyko oparcia rozumowania wyłącznie na abstrakcyjne sformułowanych tezach poszczególnych rozstrzygnięć sądowych (w tym zwłaszcza Sądu Najwyższego), co w razie ich oderwania od konkretnych stanów faktycznych, w jakich orzeczeniach te zapadły, może prowadzić do rozszerzającej i nieuzasadnionej interpretacji interesującego nas przepisu. Ogólnie rzecz ujmując, w orzecznictwie Sądu Najwyższego przyjmuje się, że przez wykonywanie pracy „na rzecz” pracodawcy należy rozumieć „uzyskiwanie” przez pracodawcę „rezultatu pracy”. Tak wypowiedział się SN w uchwale z dnia 2 września 2009 r., II UZP 6/09, która zasadniczo zapoczątkowała tę linię orzeczniczą, którą obecnie uznaje się za utrwaloną. Podobne zapatrywanie wyrażono w wyroku z dnia 22 lutego 2010 r., I UK 259/09. Chodzi więc o przysparzanie korzyści pracodawcy, zarówno materialnych, jak i niematerialnych, i to bez względu na to, czy pracownik wykonuje w ramach umowy cywilnoprawnej i umowy o pracę na rzecz swojego pracodawcy pracę tego samego rodzaju czy też pracę rodzajowo różną ${ }^{17}$. Z kolei w uzasadnieniu wyroku SN z dnia 25 maja 2010 r., I UK 354/09 ${ }^{18}$, wskazano, że

17 Zob. np. wyroki Sądu Apelacyjnego: w Szczecinie z dnia 21 kwietnia 2015 r., III AUa 640/14, LEX nr 1771371; oraz w Gdańsku z dnia 25 lutego 2015 r., III AUa 1568/14, LEX nr 1668573.

18 LEX nr 602211. 
do zakwalifikowania świadczenia prac w ramach umów cywilnoprawnych na rzecz pracodawcy, z którym zleceniobiorca pozostaje w stosunku pracy, musi istnieć bezpośredni związek między korzyścią pracodawcy, która jest wymierna i związana z realizacją celów statutowych, a pracami wykonywanymi przez jego pracowników na podstawie umów cywilnoprawnych zawieranych $\mathrm{z}$ innym podmiotem.

Czynnikiem decydującym, na rzecz jakiego podmiotu była de facto wykonywana praca, jest jej finalny efekt. W ocenie Sądu Najwyższego należy w takiej sytuacji badać, który podmiot osiąga w ostatecznym rozrachunku korzyść z wykonania umowy ${ }^{19}$. Pracodawca w wyniku umowy o podwykonawstwo przejmuje bowiem, w ostatecznym rozrachunku, rezultat pracy wykonanej na rzecz zleceniodawcy, przy czym następuje to w wyniku zawarcia umowy o świadczenie usług $\mathrm{z}$ osobą trzecią oraz zawartej umowy cywilnoprawnej między pracodawcą i zleceniodawcą ${ }^{20}$. Takie podejście zdaje się przyjmować szerokie znaczenie zwrotu „na rzecz pracodawcy”. Zdaniem P. Czarneckiego za takim podejściem przemawia użycie przez ustawodawcę pojęcia „wykonywanie pracy”, oznaczającego każdą ukierunkowaną wolą działalność człowieka, które należy przeciwstawić pojęciu „świadczenie pracy”. O tym ostatnim można mówić wtedy, gdy dana osoba oddaje pod czyjeś kierownictwo swoją zdolność wytwarzania usług czy dzieł ${ }^{21}$. Wskazują na to także cel i funkcja omawianego przepisu, jak zawarto bowiem w literaturze, ma on za zadanie przeciwdziałanie powstawaniu „trójkąta umów”, gdy jedna firma zawiera umowę-zlecenia z pracownikiem drugiej, a obie zawierają umowę o podwykonawstwo ${ }^{22}$. Jednak przy takim zapatrywaniu określenie „na rzecz” staje się synonimem pojęcia „w interesie pracodawcy”23, co w obecnych realiach gospodarczych wydaje się wnioskiem zbyt daleko idącym. Nie oddaje bowiem stopnia skomplikowania współczesnych stosunków gospodarczych. Nawet w standardowym układzie podwykonawstwa podmiot, który nawiązał cywilnoprawny stosunek zatrudnienia ze świadczącym pracę, zatrudnionym w ramach stosunku pracy u swojego kontrahenta, uzyskuje bowiem ekonomiczny zysk wynikający ze świadczenia pracy ${ }^{24}$. Zysku tego nie można marginalizować w procesie badania relacji zachodzących między tym podmiotem a pracodawcą i pracownikiem na potrzeby stosowania art. 8 ust. 2a ustawy systemowej.

Warto także pamiętać, że przytoczone wywody Sądu Najwyższego zostały sformułowane w stanach faktycznych, których zleceniobiorcę (bądź wykonawcę)

19 Tak też Sąd Apelacyjny w Gdańsku w wyroku z dnia 25 lutego 2015 r., III AUa 1568/14, LEX nr 1668573.

20 Zob. wyrok Sądu Apelacyjnego w Gdańsku z dnia 20 sierpnia 2014 r., III AUa 204/14, LEX nr 1498876.

21 P. Czarnecki, Glosa do uchwaty SN z dnia 16 czerwca 2016 r., III UZP 6/16, OSP 2017, nr 7-8, s. 27.

22 I. Jędrasik-Jankowska, Pojęcia i konstrukcje prawne ubezpieczenia społecznego, Warszawa 2010, s. 53.

23 P. Prusinowski, op. cit., s. 291.

24 S. Koczur, op. cit., s. 352. Odmiennie, jak się wydaje, P. Czarnecki, op. cit., s. 28. 
łączyła umowa ze zleceniodawcą (bądź zamawiającym), który na terenie należącym do pracodawcy i w miejscu prowadzenia przez tegoż pracodawcę działalności (i zatrudniania pracowników) świadczył usługi w ramach umowy cywilnoprawnej z tym pracodawcą. Mianowicie, w sprawie o sygn. akt II UZP 6/09 odwołująca spółka (dalej: spółka) świadczyła usługi na terenie firmy „Stocznia G. — grupa Stoczni G. S.A.” (dalej: Stocznia) i była podwykonawcą prac na jej rzecz. Spółka ta zawierała umowy cywilnoprawne (umowy o dzieło) z pracownikami Stoczni. Przedmiotem tych umów był między innymi nadzór czynności innych pracowników Stoczni, którzy wykonywali dzieło na rzecz Spółki - spawanie, montaż, trasowanie itp. Z kolei w sprawie o sygn. akt I UK 259/09 zainteresowane osoby świadczyły w ramach umów-zlecenia usługi pielęgniarskie na rzecz szpitala, z którym wiązał je stosunek pracy. Wykonywały one typowe czynności wchodzące w zakres usług medycznych, których odbiorcą był ich pracodawca, a nie zleceniodawca. Czynności objęte przedmiotem umowy-zlecenia realizowane były na oddziałach szpitala przez te osoby, które jednocześnie były związane stosunkiem pracy z tym szpitalem. W obu sprawach dla pracowników (z którymi zawarto umowę cywilnoprawną) nie zmieniało się miejsce wykonywania pracy, a podmiot, który zawierał umowę cywilnoprawną, był w istocie tylko pośrednikiem świadczonej pracy. Innymi słowy już prima facie widoczne było, że zleceniodawca (zamawiający) nie odgrywał żadnej istotnej roli w procesie wykonywania pracy, gdyż była ona wykonywana bezpośrednio na rzecz pracodawcy. Z kolei cała konstrukcja prawna miała raczej na celu skorzystanie z przepisów dotyczących zbiegu tytułów ubezpieczenia.

Warto zauważyć, że sformułowanie „na rzecz pracodawcy” znane jest konstrukcji stosunku pracy przyjętej w art. $22 \S 1$ k.p. Stanowi on, że przez nawiązanie stosunku pracy pracownik zobowiązuje się do wykonywania pracy określonego rodzaju na rzecz pracodawcy i pod jego kierownictwem oraz w miejscu i czasie wyznaczonym przez pracodawcę, a pracodawca - do zatrudniania pracownika za wynagrodzeniem. Sformułowanie wykonywania pracy na rzecz pracodawcy staje się zatem immanentną cechą stosunku pracy. Wprawdzie na gruncie prawa ubezpieczeń społecznych określone pojęcia mogą mieć charakter autonomiczny, niemniej trudno przyjąć, aby w art. 8 ust. 2a ustawy systemowej, w którym w drodze fikcji prawnej normuje się, kogo uważa się za pracownika, inaczej rozumiano wyrażenie „na rzecz pracodawcy”, tym bardziej że akurat ten przepis ma właśnie na celu ochronę stosunku pracy. W tym kontekście zwrot „na rzecz pracodawcy” w ujęciu art. 8 ust. 2a ustawy systemowej należałoby rozumieć przez pryzmat relacji zachodzącej w typowym stosunku pracy. W doktrynie prawa pracy stwierdza się, że wykonywanie pracy na rzecz pracodawcy oznacza, że pracodawca jest wierzycielem świadczenia pracy i on zawłaszcza wynik pracy ${ }^{25}$. Oznacza to zarazem, że w jest on bezpośrednim „odbiorcą” pracy wykonywanej przez pracownika.

25 J. Wratny, Kodeks pracy. Komentarz, Warszawa 2013, komentarz do art. 22, Nb. 3. 
Chodzi zatem o ten aspekt pracy ludzkiej, który w odniesieniu do pracodawcy: 1. oznacza obowiązek wykonywania jej osobiście oraz 2. rozumiany jest czynnościowo (a więc powtarzanej w codziennych lub dłuższych odstępach czasu).

Mając to na względzie, należałoby stwierdzić, że aby uznać osobę, o której mowa w art. 8 ust. 2a, za pracownika, musiałaby zostać stwierdzona konstrukcyjna cecha stosunku pracy z art. 22 k.p. Innymi słowy, mimo prawnego istnienia podmiotu trzeciego więź, jaka za pośrednictwem tego podmiotu zachodzi między zleceniobiorcą (czy wykonawcą) a podmiotem, z którym pozostaje w stosunku pracy, musiałaby w tym wąskim zakresie być analogiczna do relacji zachodzącej $\mathrm{w}$ ramach stosunku pracy. Na podobną perspektywę zwrócono uwagę w uzasadnieniu uchwały z dnia 2 września 2009 r., II UZP 6/09, w której Sąd Najwyższy stwierdził, że przepis art. 8 ust. 2a ustawy systemowej dotyczy z reguły takiej pracy wykonywanej na podstawie umowy cywilnoprawnej na rzecz pracodawcy, która mogłaby być świadczona przez jej wykonawcę w ramach stosunku pracy z tym pracodawcą, z tym że musiałby on wówczas przestrzegać przepisów o godzinach nadliczbowych, powierzeniu pracownikowi do wykonywania pracy innej niż umówiona (art. 42 § k.p.) i innych ograniczeń i obciążeń wynikających z przepisów prawa pracy.

Praktycznie rzecz ujmując, aby ustalić, czy praca wykonywana jest na rzecz pracodawcy, należałoby w pierwszej kolejności poddać analizie charakter i rolę podmiotu trzeciego oraz treść stosunku prawnego, jaki go łączy z pracodawcą. Jeśli mamy do czynienia ze świadczeniem usługi, a rolą podmiotu trzeciego jest w istocie pośrednictwo pracy (co zbliżałoby przedmiot jego działalności do agencji pracy tymczasowej), to należałoby przyjąć, że w ramach umowy zlecenia świadczona jest praca na rzecz pracodawcy. Istnienie podmiotu trzeciego nie zmienia zatem faktu, że bezpośrednim beneficjentem świadczonej pracy (w ujęciu czynnościowym) jest pracodawca. Podobnie rzecz by się przedstawiała przy ustaleniu, że wykonywana była praca tego samego (bądź podobnego) rodzaju jak praca wykonywana w stosunku pracy czy charakterystyczna dla stanowiska, na którym nastąpiło zatrudnienie.

Zupełnie inaczej należałoby natomiast ocenić sytuację, w której podmiot trzeci zobowiązany jest do dostarczania pracodawcy określonego produktu, który wytwarza w ramach prowadzonej przez siebie działalności. Wówczas, jak się wydaje, kluczowe jest ustalenie, czy ponosi on ryzyko organizacyjne, techniczne, produkcyjne, a także osobowe za produkt przez siebie wytwarzany. Chodzi zatem o stany faktyczne, gdy pracodawca kupuje określony produkt od podmiotu trzeciego, u którego w ramach umowy cywilnoprawnej zatrudniony jest przy produkcji pracownik tego pracodawcy. Taka sytuacja nie powinna być objęta hipotezą art. 8 ust. 2 a ustawy systemowej ${ }^{26}$. Należy bowiem zauważyć, że jeśli ryzyko organizacyjne, technologiczne, produkcyjne (zakup materiałów produkcyjnych od nieza-

${ }^{26}$ Podobnie S. Koczur, op. cit., s. 356, przypis 10. 
leżnych producentów, wytworzenie produktów bez wad) spoczywa na podmiocie trzecim (jako wytwórcy), wówczas „beneficjentem” pracy osoby zatrudnionej na podstawie stosunku cywilnoprawnego przy wytarzaniu tego produktu jest wyłącznie wytwórca. To on uzyskuje w wyniku świadczenia pracy przez osobę, z którą zawarł umowę cywilnoprawną, korzyść w postaci finalnego produktu gotowego (produktu pracy), jaki może sprzedać dowolnemu podmiotowi. Bez znaczenia jest, komu ów produkt zostanie zbyty i na jakich zasadach. Sprzedaż wytworzonego produktu akurat pracodawcy nie pozwala na przyjęcie, że praca w ramach umowy cywilnoprawnej świadczona jest na rzecz tego pracodawcy. Zleceniobiorca (bądź wykonawca) świadczy usługę (wykonuje dzieło) bezpośrednio na rzecz zleceniodawcy (wykonawcy) jako wytwórcy produktu. Oceny tej nie zmienia też okoliczność, że podmiot trzeci jest jedynym dostawcą danego produktu dla pracodawcy bądź uzyskuje korzyści tylko z tego stosunku prawnego. Różnicowanie sytuacji osoby wykonującej pracę na podstawie umowy cywilnoprawnej w zależności od tego, na czyją rzecz podmiot trzeci dokona zbycia produktu, nie znajduje bowiem żadnych podstaw w obowiązujących przepisach i jest ograniczeniem konstytucyjnej swobody działalności gospodarczej. Istotne natomiast, że to na podmiocie trzecim spoczywa wskazane tu ryzyko organizacyjne i technologiczne. Chodzi zatem o wyłączną jego odpowiedzialność za zorganizowanie procesu produkcji, w tym przykładowo zakup towarów koniecznych do ich wytworzenia, posiadanie środków produkcji czy odpowiedzialność podmiotu trzeciego wobec pracodawcy za sprzedany produkt. W takich przypadkach stosowanie art. 8 ust. 2a ustawy systemowej należałoby uznać za nieuzasadnione.

\section{OCENA ZGODNOŚCI Z KONSTYTUCJĄ RP PRZEPISU ART. 8 UST. 2A USTAWY SYSTEMOWEJ}

W zakresie odnoszącym się do sytuacji, gdy osoba zatrudniona przez podmiot trzeci na podstawie umowy cywilnoprawnej wykonuje w ramach tej umowy pracę na rzecz swojego pracodawcy, art. 8 ust. 2a ustawy systemowej nie określa, kto powinien zostać uznany za płatnika składek należnych od wynagrodzenia wypłaconego na podstawie tej umowy. Artykuł 4 pkt 2 lit a) ustawy systemowej wskazuje, że płatnikiem wobec pracowników jest pracodawca. W świetle brzmienia art. 8 ust. 2a ustawy systemowej można bronić poglądu, że przewidziana w nim fikcja prawna uznania za pracownika strony stosunku cywilnoprawnego powinna prowadzić do stwierdzenia, że druga strona tego stosunku prawnego uznawana jest za pracodawcę tej pierwszej strony w rozumieniu art. 4 pkt 2 lit. a) ustawy systemowej. Takie zapatrywanie było zresztą postulowane w literaturze ${ }^{27}$. Na gruncie omawianego przepisu Sąd Najwyższy uznał jednak, że obowiązek zgłoszenia do

27 I. Jędrasik-Jankowska, Pojęcia i konstrukcje prawne..., 2010, s. 48-49. 
wymienionych ubezpieczeń społecznych i zapłatę należnych składek ma podmiot pozostający w stosunku pracy z osobą wykonującą pracę na podstawie umowy agencyjnej, umowy-zlecenia lub innej umowy o świadczenie usług, do której stosuje się przepisy dotyczące zlecenia albo umowy o dzieło ${ }^{28}$. W takim ujęciu pracodawca pełni funkcję płatnika składek należnych od kwot wynagrodzenia $\mathrm{z}$ tytułu umów, których nie jest stroną i o których zawarciu może nawet nie wiedzieć; może także nie mieć informacji na temat wysokości wynagrodzenia wypłacanego przez podmiot trzeci, choć informacja ta ma podstawowe znaczenie dla prawidłowego wypełniania obowiązków płatnika. Pogląd Sądu Najwyższego wywołuje ponadto wiele problemów związanych z ochroną danych osobowych czy dopuszczalnością wprowadzania zakazów zatrudnienia u kontrahenta pracodawcy ${ }^{29}$.

Ukształtowana w orzecznictwie treść art. 8 ust. 2a wywołuje istotne wątpliwości w zakresie jej zgodności z zasadą ochrony zaufania do państwa i stanowionego przez nie prawa. Istotne przy tym, że norma ta może być samoistnym przedmiotem kontroli konstytucyjnej. W dotychczasowym orzecznictwie Trybunału Konstytucyjnego ukształtowany został bowiem pogląd, że jeżeli utrwalona i konsekwentna praktyka stosowania prawa w sposób bezsporny ustaliła wykładnię danego przepisu prawnego, a jednocześnie przyjęta interpretacja nie jest kwestionowana przez przedstawicieli doktryny, to przedmiotem kontroli konstytucyjności może być norma prawna dekodowana $\mathrm{z}$ danego przepisu zgodnie $\mathrm{z}$ ustaloną prakty$\mathrm{ką}^{30}$. Szczególnie dobitnie wyrażono ten pogląd w wyroku z dnia 27 października 2010 r., sygn. K 10/08 ${ }^{31}$. W orzeczeniu tym Trybunał Konstytucyjny przypomniał dominujące w orzecznictwie stanowisko, zgodnie z którym , jeżeli określony sposób rozumienia przepisu ustawy znalazł jednoznaczny i autorytatywny wyraz w orzecznictwie Sądu Najwyższego bądź Naczelnego Sądu Administracyjnego, to należy uznać, że przepis ten — w praktyce swego stosowania — nabrał takiej właśnie treści, jaką odnalazły w nim najwyższe instancje sądowe"32.

W tym kontekście trzeba podkreślić, że choć zasada zaufania do państwa i stanowionego przez nie prawa nie została wprost wyrażona w tekście Konstytu-

28 Zob. uchwałę Sądu Najwyższego z dnia 2 września 2009 r., II UZP 6/09; oraz wyrok tego Sądu z dnia 18 października 2011 r., III UK 22/11, OSNP 2012, nr 21-22, poz. 266.

29 M. Raczkowski, Zatrudnienie pracownika u kontrahenta pracodawcy, [w:] Umowy cywilnoprawne w ubezpieczeniach społecznych, red. M. Szabłowska-Juckiewicz, J. Wantoch-Rekowski, M. Wałachowska, Warszawa 2015, s. 336-370.

30 Tak postanowienie Trybunału Konstytucyjnego z dnia 4 grudnia 2000 r., SK 10/99, OTK ZU 2000, nr 8, poz. 87; wyrok TK z dnia 3 października 2000 r., K 33/99, OTK ZU 2000, nr 6, poz. 188; postanowienie z 19 lipca 2005 r., SK 37/04, OTK ZU 2005, nr 7/A.

31 OTK ZU 2010, nr 8A, poz. 81.

32 Zob. przede wszystkim wyrok Trybunału Konstytucyjnego z dnia 28 października 2003 r., P 3/03, OTK ZU, 2003, nr 8/A, poz. 82; oraz orzeczenia Trybunału Konstytucyjnego z dnia 8 maja 2000 r., SK 22/99, OTK ZU 2000, nr 4, poz. 107; z dnia 6 września 2001 r., P 3/01, OTK ZU 2001, nr 6, poz. 163; z dnia 28 stycznia 2003 r., SK 37/01, OTK ZU 2003, nr 1/A, poz. 3; z dnia 3 czerwca 2008 r., K 42/07, OTK ZU 2008, nr 5/A, poz. 77. 
cji, to jednak - jak przyjmuje się w orzecznictwie Trybunału Konstytucyjnego - „należy niewątpliwie do kanonu zasad składających się na pojęcie państwa prawnego w znaczeniu, w jakim pojęcie to występuje w art. 2 konstytucji” 33 . Zasada ta, jak wyjaśnił Trybunał, jest szczególnie ważna w odniesieniu do prawa danin publicznych, gdyż zakłada pewność prawa, to znaczy zespół takich jego cech zapewniających jednostce bezpieczeństwo prawne i umożliwiających jej decydowanie o swoim postępowaniu na podstawie pełnej znajomości przesłanek działania organów państwowych oraz konsekwencji prawnych, jakie ich działania mogą pociągnąc za sobą ${ }^{34}$. Jej istotą jest zakaz tworzenia przez ustawodawcę „pułapek” na adresatów przepisów prawnych ${ }^{35}$. Lojalność państwa wobec obywateli wymagana jest zwłaszcza, gdy dana regulacja prawna jest podstawą podejmowania działań przez jednostkę w taki sposób, by obywatel mógł układać swoje sprawy w zaufaniu, że nie naraża się na skutki prawne, których nie mógł przewidzieć ${ }^{36}$. Tymczasem w świetle utrwalonego orzecznictwa Sądu Najwyższego, jak już wskazano, pracodawca pełni funkcję płatnika składek należnych od kwot, których wysokość nie zależy od jego roli, wypłacanych na podstawie umów, których nie jest stroną i o których zawarciu może nawet nie wiedzieć. Jest to o tyle istotne, że w orzecznictwie Trybunału Konstytucyjnego przyjmuje się, iż składka na ubezpieczenia społeczne w części opłacanej przez płatnika nosi wszelkie cechy odrębnej niepodatkowej daniny publicznej, o której mowa w art. 217 Konstytucji ${ }^{37}$.

Jednocześnie, o ile na gruncie ustawy z dnia 29 sierpnia 1997 r. o ochronie danych osobowych ${ }^{38}$ można próbować bronić poglądu, że w wypadku pracodawcy-płatnika składek na ubezpieczenia społeczne pracowników, o jakich mowa $\mathrm{w}$ art. 8 ust. 2a ustawy systemowej przetwarzanie informacji o przychodach uzyskiwanych z wykonania wymienionych w tym przepisie umów cywilnoprawnych jest konieczne do wykonywania obowiązku wynikającego z przepisów prawa w rozumieniu art. 23 ust. 1 pkt 2 u.o.d.o. ${ }^{39}$, o tyle sytuacja ta skomplikuje się po rozpoczęciu stosowania rozporządzenia Parlamentu Europejskiego i Rady (UE)

33 Tak wyrok Trybunału Konstytucyjnego z dnia 10 lipca 2000 r., SK 21/99, OTK ZU 2000, nr 5, poz. 144.

34 Wyrok Trybunału Konstytucyjnego z dnia 15 czerwca 2000 r., P. 3/00, OTK ZU 2000, nr 5, s. 690-691.

35 Orzeczenie Trybunału Konstytucyjnego z dnia 3 grudnia 1996 r., K 25/95, OTK-A 2011, nr 6, poz. 57; wyroki z dnia: 10 kwietnia 2001 r., U 7/00, OTK 2001, nr 3, poz. 56 ; 5 listopada 2002 r., P 7/01, OTK-A 2002, nr 6, poz. 80; 7 czerwca 2004 r., P 4/03, OTK-A 2004, nr 6, poz. 55; 15 lutego 2005 r., K 48/04, OTK-A 2005, nr 2, poz. 15; 29 listopada 2006 r., SK 51/06, OTK-A 2006, nr 10, poz. 156; 20 stycznia 2009 r., P 40/07, OTK-A 2009, nr 1, poz. 4.

36 Tak np. orzeczenie Trybunału Konstytucyjnego z dnia 24 maja 1994 r., K 1/94, OTK ZU 1986-1995, t. 5, poz. 10.

37 Wyrok TK z dnia 15 lipca 2013 r., K7/12, OTK ZU 2013, nr 6A, poz. 76.

38 Dz.U. z 2016 r. poz. 922 (dalej: u.o.d.o.).

39 Por. wyrok Sądu Najwyższego z dnia 18 października 2011 r., III UK 22/11, OSNP 2012, nr 21-22, poz. 266. 
2016/679 z dnia 27 kwietnia 2016 r. w sprawie ochrony osób fizycznych w związku z przetwarzaniem danych osobowych i w sprawie swobodnego przepływu takich danych oraz uchylenia dyrektywy 95/46/WE (ogólnego rozporządzenia o ochronie danych $)^{40}$. Na gruncie art. 6 ust. 1 lit. c przetwarzanie danych osobowych jest wprawdzie dozwolone, jeżeli jest niezbędne do wypełnienia obowiązku prawnego ciążącego na administratorze danych, niemniej jednak w świetle art. 6 ust. 3 RODO podstawa takiego przetwarzania musi być wyraźnie zawarta w prawie Unii Europejskiej lub w prawie państwa członkowskiego, któremu podlega administrator. Tymczasem art. 8 ust. 2a nie określa wprost podmiotu, który w sytuacji wykonywania pracy na rzecz własnego pracodawcy w ramach umowy cywilnoprawnej zawartej z innym podmiotem powinien pełnić funkcję płatnika.

Taki stan rzeczy wywołuje także inne zastrzeżenia natury konstytucyjnej. Zgodnie ze wskazanym art. 217 Konstytucji RP nakładanie podatków, innych danin publicznych, określanie podmiotów, przedmiotów opodatkowania i stawek podatkowych, a także zasad przyznawania ulg i umorzeń oraz kategorii podmiotów zwolnionych od podatków następuje ustawą. Przepis ten ma charakter gwarancyjny, co przejawia się w ustanowieniu wyższych standardów zarówno co do zupełności regulacji, jak i jej klarowności ${ }^{41}$. Trybunał wielokrotnie podkreślał, że „dziedziną, w której nakaz określoności wymaga szczególnego zaakcentowania jest - obok prawa karnego — także dziedzina prawa daninowego" ${ }^{\text {,42 }}$. W konsekwencji za naruszenie zasad konstytucyjnych uważane jest formułowanie niejasnych i nieprecyzyjnych przepisów daninowych, które powodują niepewność jego adresatów co do ich praw i obowiązków ${ }^{43}$.

Artykuł 8 ust. 2a ustawy systemowej w zakresie, w jakim odnosi się do sytuacji wykonywania pracy na rzecz własnego pracodawcy w ramach umowy cywilnoprawnej zawartej z innym podmiotem, tych standardów nie spełnia. Nie określa on bowiem jednoznacznie adresata obowiązku ponoszenia daniny publicznej w postaci składki na ubezpieczenia społeczne w części finansowanej przez płatnika, co powoduje niepewność adresatów przepisów określających obowiązki płatnika składek na ubezpieczenia społeczne co do zakresu ciążących na nich powinności dotyczących obliczania, potrącania z dochodów ubezpieczonych, roz-

40 Dz.Urz. UE L z dnia 4 maja 2016 r. nr 119, s. 1 (dalej: RODO).

41 T. Dębowska-Romanowska, Dylematy interpretacyjne artykułu 217 Konstytucji, [w:] Ex iniuria non oriturius. Księga ku czci profesora Wojciecha Łączkowskiego, red. A. Gomułowicz, J. Małecki, Poznań 2003, s. 220.

42 Zob. też inne orzeczenia: uchwała z dnia 16 stycznia 1996 r., W. 12/94, OTK ZU 1996, nr 1, poz. 4; wyroki z dnia: 10 października 1998 r., K. 39/97, OTK ZU 1998, nr 5, poz. 99; 13 lutego 2001 r., K. 19/99, OTK ZU 2001, nr 2, poz. 30; z 20 listopada 2002 r., K 41/02, OTK ZU 2002, nr 6A, poz. 83.

43 Zob. wyrok Trybunału Konstytucyjnego z dnia 26 maja 2009 r., P 58/07, OTK-A 2009, nr 5, poz. 71 . 
liczania i opłacania tychże składek ${ }^{44}$. Analogiczny zarzut można sformułować wobec art. 8 ust. 2a ustawy systemowej w zakresie jego zgodności z art. 64 ust. 2 Konstytucji RP. Ten ostatni stanowi, że własność, inne prawa majątkowe oraz prawo dziedziczenia podlegają równej dla wszystkich ochronie prawnej. Zgodnie zaś $\mathrm{z}$ art. 64 ust. 3 Konstytucji RP wszelkie ograniczenia w zakresie korzystania z prawa własności mogą być ustanawiane „tylko w ustawie” i muszą spełniać wymóg dostatecznej określoności ${ }^{45}$. Podstawa ustawowa, o której mowa w art. 64 ust. 3 Konstytucji RP, musi mieć na tyle rozwinięte ujęcie, by czyniła zadość wymaganiu dostatecznej „określoności” ${ }^{\natural}$. Trudno za tak określony uznać natomiast art. 8 ust. 2a ustawy systemowej, skoro jego wykładnia językowa pozwala na uznanie za płatnika składek odpowiedzialnego własnym majątkiem za opłacanie składek należnych od wynagrodzenia wymienionej w nim strony umowy cywilnoprawnej zarówno jej pracodawcy, jak i drugiej strony tejże umowy.

Odnotowania wymaga przy tym, że te zarzuty odnoszą się do tej części składki, która finansowana jest przez płatnika, oraz składek, które płatnik finansuje w całości z własnych środków. Trudno natomiast formułować analogiczne zarzuty z perspektywy ubezpieczonego, dla którego uznanie za pracownika stwarza wystarczającą podstawę ograniczenia jego praw majątkowych do wynagrodzenia w części odpowiadającej finansowanej przez niego składki na ubezpieczenia społeczne. Należy jednak podkreślić, że ze względu na konstrukcję składki ubezpieczenia społecznego stwierdzenie zakresowej tylko niezgodności art. 8 ust. 2a ustawy systemowej z Konstytucją RP, dotyczącej tej części składek, która jest finansowana przez płatnika, prowadziłoby do wtórnego naruszenia zasady równości płatników, jaka wynika z art. 32 ust. 1 Konstytucji RP. Niedopuszczalne wydaje się bowiem różnicowanie obowiązków płatników w zależności od tego, z jaką kategorią pracownika mamy do czynienia - czy osobą, która zawarła z płatnikiem umowę o pracę, czy osobą uznaną jedynie za pracownika na podstawie przepisu przewidującego fikcję prawną. Należy więc postulować doprecyzowanie ustawy systemowej w zakresie odnoszącym się do konsekwencji uznania za pracownika osoby wykonującej na rzecz swojego pracodawcy pracę na podstawie umowy agencyjnej, umowy-zlecenia lub innej umowy o świadczenie usług, do której zgodnie z kodeksem cywilnym stosuje się przepisy dotyczące zlecenia albo umowy o dzieło. Niezbędne jest bowiem wyraźne przesądzenie, kto w takim przypadku pełni funkcję płatnika składek należnych od wynagrodzenia osoby uznanej za pracownika.

44 Podobnie, choć z nieco innym uzasadnieniem, Rzecznik Praw Obywatelskich w stanowisku złożonym do sprawy K 15/16, http://ipo.trybunal.gov.pl/ipo/dok?dok=F1463840045\%2FK_15_16_ rpo_2016_06_29_ADO.pdf (dostęp: 22.01.2018).

45 Wyrok TK z dnia 18 marca 2010 r., K 8/08, OTK-A 2010, nr 3, poz. 23.

46 Zob. wyrok Trybunału Konstytucyjnego z 21 marca 2001 r., K 24/00, OTK ZU 2001, nr 3 , poz. 51. 
W tym kontekście, de lege ferenda, pożądane wydaje się doprecyzowanie w art. 8 ust. 2 a ustawy systemowej, że płatnikiem w stosunku do osoby wykonującej pracę na podstawie umowy agencyjnej, umowy-zlecenia lub innej umowy o świadczenie usług, do której zgodnie z kodeksem cywilnym stosuje się przepisy dotyczące zlecenia albo umowy o dzieło, jeżeli w ramach takiej umowy wykonuje pracę na rzecz pracodawcy, z którym pozostaje w stosunku pracy, jest podmiot będący drugą stroną umowy-zlecenia, umowy o świadczenie usług albo umowy o dzieło. Pozwoli to na uniknięcie wielu sygnalizowanych w piśmiennictwie trudności w zakresie ochrony danych osobowych czy dopuszczalności wprowadzania zakazów zatrudnienia u kontrahenta pracodawcy związanych z uznaniem pracodawcy za płatnika w sytuacji, o której mowa w art. 8 ust. 2a in fine ustawy systemowej.

\section{PODSUMOWANIE}

Przeprowadzone rozważania skutkują kilkoma zasadniczymi wnioskami. Po pierwsze, przy interpretacji zawartego w art. 8 ust. 2a ustawy systemowej wyrażenia ,jeżeli w ramach takiej umowy wykonuje pracę na rzecz pracodawcy, z którym pozostaje w stosunku pracy" należy z rozwagą odwoływać się do ogólnych tez orzeczeń Sądu Najwyższego. Chodzi mianowicie o to, aby tezy te znajdowały zastosowanie w adekwatnych stanach faktycznych. To one wyznaczają bowiem możliwość zastosowania normy prawnej wyrażonej w tym przepisie. Aby zatem oprzeć rozstrzygnięcie na art. 8 ust. 2a ustawy systemowej, każdorazowo należałoby wykazać, że w ramach umowy cywilnoprawnej praca była wykonywana „na rzecz pracodawcy”. To z kolei wymaga uwzględnienia nie tylko okoliczności konkretnego przypadku (w tym zwłaszcza roli podmiotu trzeciego), lecz także analizy omawianego wyrażenia w kontekście znaczenia, jakie tożsamemu zwrotowi przypisuje się w art. $22 \S 1$ k.p. Po drugie, ukształtowana w orzecznictwie treść normatywna art. 8 ust. 2a ustawy, zgodnie z którą pracodawca musi pełnić funkcję płatnika składek należnych od kwot wynagrodzenia z tytułu umów, których nie jest stroną i o których zawarciu może nawet nie wiedzieć, nie spełnia standardów wynikających z zasady zaufania obywateli do państwa i stanowionego przez nie prawa. Po trzecie, jako że art. 8 ust. 2a ustawy systemowej nie określa jednoznacznie adresata obowiązku ponoszenia daniny publicznej w postaci składki na ubezpieczenia społeczne w części finansowanej przez płatnika, pozostaje on w sprzeczności z art. 217 oraz art. 64 ust. 2 i 3 Konstytucji RP. Po czwarte, de lege ferenda należy postulować doprecyzowanie w art. 8 ust. 2a ustawy systemowej, że płatnikiem w stosunku do osoby wykonującej pracę na podstawie umowy agencyjnej, umowy-zlecenia lub innej umowy o świadczenie usług, do której zgodnie z kodeksem cywilnym stosuje się przepisy dotyczące zlecenia albo umowy o dzie- 
ło, jeżeli w ramach takiej umowy wykonuje pracę na rzecz pracodawcy, z którym pozostaje w stosunku pracy, jest podmiot będący drugą stroną umowy-zlecenia, umowy o świadczenie usług albo umowy o dzieło.

\title{
ON CONTROVERSIES OVER INTERPRETATION OF THE PHRASE "PERFORMING WORK FOR THE BENEFIT OF ONE'S EMPLOYER" WITHIN THE MEANING OF ARTICLE 8 SECTION 2A OF THE SOCIAL INSURANCE SYSTEM ACT AND CONSTITUTIONALITY OF THAT PROVISION
}

\begin{abstract}
Summary
The article discusses controversies over interpretation of the phrase "performing work for the benefit of one's own employer" within the meaning of Article 8 section 2a of the Social Insurance System Act. The author criticizes interpretation of this phrase based solely on abstract theses formulated in individual judicial decisions, especially the ones of the Supreme Court. When detached from facts on which they were based, they can lead to unreasonable interpretation of the provision in question. The phrase "for the benefit of one's own employer", should be construed through the prism of a relation that takes place in a typical employment relationship. In the three-subject configuration, when services are provided to the employer and the role of the third party is reduced to placement of workers (which makes them similar, in terms of scope of their business, to temporary work agencies), this results in recognition that under service contracts concluded with those workers work is provided for their employer. It is quite different for the situation where the third party is obliged to provide employer with a particular product, which is produced in the course of their business. Then, the key factor should rely on establishing whether the party in question bears organizational, technical and production risks related to manufactured products. Furthermore, considerations contained herein lead to the conclusion that the normative content of Article 8 section 2a of the Social Security Act settled in the Supreme Court's case-law is incompatible with the principle of citizens' trust in the state and its law. Article 8 section 2a of the Social Security Act itself, at least when it comes to performing work for one's own employer within a civil-law contract concluded with a third party, is incompatible with Articles 217 and 64 section 3 of the Constitution of the Republic of Poland. Thus, opinions on how the law should stand were made herein.
\end{abstract}

Keywords: employer, social insurance, performing work for the benefit of one's own employer

\section{BIBLIOGRAFIA}

Antonów K., Zakres podmiotowy obowiazkowego ubezpieczenia emerytalnego, [w:] Konstrukcje prawa emerytalnego, red. T. Bińczycka-Majewska, Kraków 2004.

Czarnecki P., Glosa do uchwaty SN z dnia 16 czerwca 2016 r., III UZP 6/16, OSP 2017, nr 7-8.

Dębowska-Romanowska T., Dylematy interpretacyjne artykułu 217 Konstytucji [w:] Ex iniuria non oriturius. Księga ku czci profesora Wojciecha Łaczkowskiego, red. A. Gomułowicz, J. Małecki, Poznań 2003.

Dzienisiuk D., Prawo pracy a prawo ubezpieczeń społecznych, Warszawa 2016. 
Jędrasik-Jankowska I., Konstrukcja uznania za pracownika w prawie ubezpieczenia społecznego, „Praca i Zabezpieczenie Społeczne” 2011, nr 8.

Jędrasik-Jankowska I., Pojęcia i konstrukcje prawne ubezpieczenia społecznego, Warszawa 2010. Jędrasik-Jankowska I., Pojęcia i konstrukcje prawne ubezpieczenia społecznego, t. 1, Warszawa 2006. Jończyk J., Prawo zabezpieczenia społecznego, Kraków 2006.

Koczur S., Beneficjent pracy jako kryterium objęcia systemem ubezpieczeń społecznych, „Monitor Prawa Pracy" 2013, nr 7.

Kubot Z., Szczególne formy zatrudnienia i samozatrudnienia, [w:] Szczególne formy zatrudnienia, red. Z. Kubot, Wrocław 2000.

Lach D., [w:] Ustawa o systemie ubezpieczeń społecznych. Komentarz, red. B. Gudowska, J. Strusińska-Żukowska, Warszawa 2014.

Prusinowski P., Obowiazek zapłaty składek a definicja pracownika w prawie ubezpieczeń społecznych, „Monitor Prawa Pracy” 2011, nr 6.

Raczkowski M., Zatrudnienie pracownika u kontrahenta pracodawcy, [w:] Umowy cywilnoprawne w ubezpieczeniach społecznych, red. M. Szabłowska-Juckiewicz, J. Wantoch-Rekowski, M. Wałachowska, Warszawa 2015.

Szpor G., System ubezpieczeń społecznych. Zagadnienia podstawowe, Warszawa 2009.

Ustawa o systemie ubezpieczeń społecznych. Komentarz, red. B. Gudowska, J. Strusińska-Żukowska, Warszawa 2014.

Wratny J., Kodeks pracy. Komentarz, Warszawa 2013. 